\title{
Human Papilloma Virus-16 and 18 Infection and the Cervical Cytology Changes in Combined Hormonal Contraceptive Users
}

\author{
Infeksi Human Papilloma Virus Tipe 16 dan 18 dan Perubahan Sitologi \\ Serviks pada Akseptor Kontrasepsi Hormonal Kombinasi \\ Merdyana Darkuthni, Mardiah Tahir, Josephine L Tumedia \\ Department of Obstetrics and Gynecology \\ Faculty of Medicine Universitas Hasanuddin/ \\ Dr. Wahidin Sudirohusodo Hospital \\ Makassar
}

\begin{abstract}
Objective: To evaluate the correlation between HPV-16 and 18 infection and the cervical cytology changes among combination hormonal contraceptives users.

Methods: A cross-sectional study involved 40 women using combined hormonal contraceptive (oral or injection/DMPA contraceptive) and 40 women of non-hormonal contraceptive users was conducted in Dr. Wahidin Sudirohusodo hospital, some affiliated hospitals of Department of Obstetrics and Gynecology Faculty of Medicine, Universitas Hasanuddin and a private clinic in Makassar from November 2015 and April 2016. HPV 16 and 18 genotyping in cervix using PCR method and cervical cytology changes using liquid-based cytology (LBC) method were performed. HPV infection and cervical cytology changes were analysis based on Fisher's test and chi-square test.
\end{abstract}

Results: A significant difference found only in parity $(\mathrm{p}<0.05)$ between users and control of baseline characteristics. Neither users nor control were significantly associated with HPV-16 and 18 infection and changes in cervical cytology.

Conclusion: Combined hormonal contraceptives are not correlated with HPV-16 and 18 infection and changes in cervical cytology.

[Indones J Obstet Gynecol 2018; 6-3: 188-192]

Keywords: cervix, combined hormonal contraceptive, human papilloma virus

\begin{abstract}
Abstrak
Tujuan: Untuk mengetahui hubungan antara HPV-16 dan 18 infeksi dan perubahan sitologi serviks pada akseptor kontrasepsi hormonal kombinasi.

Metode: Penelitian potong lintang pada 40 perempuan akseptor kontrasepsi hormonal kombinasi (oral atau injeksi/DMPA kontrasepsi) dan 40 perempuan bukan akseptor kontrasepsi hormonal kombinasi dilakukan di rumah sakit Dr. Wahidin Sudirohusodo, beberapa rumah sakit afiliasi dari Departemen Obstetri dan Ginekologi Fakultas Kedokteran Universitas Hasanuddin dan klinik swasta di Makassar dari November 2015 dan April 2016. Pemeriksaan genotip HPV 16 dan 18 dari serviks dilakukan dengan metode PCR dan pemeriksaan sitologi serviks menggunakan metode sitologi berbasis cairan (liquid based cytology). Infeksi HPV dan perubahan sitologi serviks analisis dengan uji Fischer dan uji chi-square.

Hasil: Perbedaan bermakna antara akseptor kontrasepsi hormonal kombinasi dan kontrol hanya terdapat pada paritas $(p<0,05)$ pada karakteristik sampel penelitian. Baik akseptor kontrasepsi hormonal kombinasi maupun kontrol tidak berkorelasi bermakna dengan infeksi HPV-16 dan 18 dan perubahan sitologi pada serviks.

Kesimpulan: Kontrasepsi hormonal kombinasi tidak berkorelasi dengan infeksi HPV-16 dan 18 dan perubahan sitologi pada serviks. [Maj Obstet Ginekol Indones 2018; 6-3: 188-192]

Kata kunci: human papilloma virus, kontrasepsi hormonal kombinasi, serviks
\end{abstract}

\section{INTRODUCTION}

Cervical cancer is the second most prevalent cancer among women worldwide and the main cause of death, especially in young women. Approximately 500,000 new cases registered each year out of which 250,000 cases are attributable deaths according to the World Health Organization (WHO) statistics. ${ }^{1}$ Approximately $90 \%$ of the cervical cancer deaths are in developing countries compared to other regions. ${ }^{2}$
Human papilloma virus is a DNA virus that infected skin and mucous in the lower genital tract. Approximately 95\% incidence of cervical carcinoma associated with oncogenic HPV types; HPV 16 and 18 are the most prominent oncogenic HPV types found for more than $62 \%$ in cervical carcinoma. In addition to HPV infection, the incidence of cervical carcinoma increase with sexual activity, parity, pregnancy, smoking and oral contraceptive use. ${ }^{1}$ 
Previous studies have shown that hormonal contraceptives use associated with HPV infection. Oral hormonal contraceptives use for more than six years associated with the prevalence of HPV infection in women aged 20-37 years in Thailand after controlling for sexual activity and cervical cytologic abnormalities. Current use of oral contraceptive also associated with HPV 16 and 18 seropositive. ${ }^{3}$ A study has also found that current users of oral contraceptive had a lower risk of HPV infection compared to current users of injectables users. $^{4}$ Therefore, hormonal contraceptive use increased persistent HPV infection. ${ }^{5}$

Estrogen and progestin in combined hormonal contraceptive affect the cervical cytology. Oral contraceptive cause cervical hypertrophy, hypersecretion and proliferation of endocervical gland that results in increased cervical mucus secretion, mucous edematous and pseudodecidualization. These are due to gestagen that contained in birth control pills. In addition, gestagen also causes metaplasia and epithelial dysplasia in the epithelial of portio and endocervical mucous membranes. ${ }^{6}$ Hormonal contraceptives maintained the columnar epithelial cells in the ectocervix and transformation zone (cervical ectopy). Cervical ectopy occurs when columnar epithelium found in the endocervical area extends out on to the ectocervix. Cervical ectopy is common in young women, pregnant women and hormonal contraceptive users. Some hypothesise that hormonal contraceptive users biologically more vulnerable to HPV infection than non-users. ${ }^{5,7}$ Our study aimed to evaluate the correlation between HPV-16 and 18 infection and the cervical cytology changes among combination hormonal contraceptives users.

\section{METHODS}

This cross-sectional study involved combined hormonal contraceptive users (oral and injection/ DMPA contraceptive) in Dr. Wahidin Sudirohusodo hospital, some affiliated hospitals of Department of Obstetrics and Gynecology Faculty of Medicine, Universitas Hasanuddin and a private clinic in Makassar from November 2015 and April 2016. As controls, we enrolled women of non-hormonal contraceptive users. The inclusion criteria consisted of using combined hormonal contraceptives for at least 2 years, age of first sexual intercourse $\geq 20$ years, history of normal delivery for four times maximum, one sexual partner, no smoking, alcohol and drugs, and not being treated with antibiotics. Exclusion criteria were non-users of combined hormonal contraceptives suffering from cervical carcinoma, having sexual intercourse within 3 days prior to the examination and menstruation. This study was approved by the Health Research Ethics Committee of Faculty of Medicine, Universitas Hasanuddin. All participants provided written informed consent prior to the start of the study. HPV 16 and 18 genotyping in cervix using PCR method and cervical cytology changes using liquid-based cytology (LBC) method.

A total 101 women were enrolled in this study. There were three women at enrollment who were excluded, and 18 women were drop out from this study. Therefore, 80 women $(n=80)$ were eligible for analysis in this study. The statistical analysis was based on Fisher's test and chi-square test. A p-value less than 0.05 was considered statistically significant.

\section{RESULTS}

The study included 40 women using combined hormonal contraceptives, and 40 women do not use this contraceptives method as control. Women in users group were aged between 20 and 35 years $(72.5 \%)$, high education (82.5\%), age of first sexual intercourse between 20 and 29 years (100\%), multiparity (70\%) and more than 3 years of using this contraceptive method $(67.5 \%)$ compared to control $(65 \% ; 97.5 \% ; 90 \% ; 47.5 \% ; 42.5 \%$; respectively). The only significant difference found in parity between users and control $(p<0.05)$. Baseline characteristics of the women in this study are summarized in Table 1.

HPV 16 infection detected only in one user (2.55) than none in control otherwise in HPV 18 infection. There was no significant correlation ( $p>0.05$ ) between HPV-16 and 18 infection and combined hormonal contraceptives (Table 2). Cervical cytology using LBC method show cervical changes in $24(60 \%)$ of combined hormonal contraceptives users compared to $19(47.5 \%)$ in control. There were no significant cervical cytology changes between users and control group (Table $3)$. 
Table 1. Baseline Characteristics of Study Participants

\begin{tabular}{lccccc}
\hline \hline Characteristics & \multicolumn{2}{c}{ Users (n=40) } & Control (n=40) & p \\
& n & \% & n & \% & \\
\hline Age (years) & & & & & \\
$20-35$ & 29 & 72.5 & 26 & 65 & 0.469 \\
$>35$ & 11 & 27.5 & 14 & 35 & \\
Education & & & & & \\
Low (<SMA) & 7 & 17.5 & 1 & 2.5 & 0.057 \\
High (>SMU) & 33 & 82.5 & 39 & 97.5 & \\
Occupation & & & & & \\
Working & 20 & 50 & 28 & 70.0 & 0.068 \\
Not working & 20 & 50 & 12 & 30.0 & \\
Age of first sexual intercourse (years) & & & & & \\
$20-29$ & 40 & 100 & 36 & 90 & 0.116 \\
30 - 39 & 0 & 0 & 4 & 10 & \\
Parity & & & & & \\
Nulli/Primipara & 10 & 25 & 21 & 52.5 & 0.012 \\
Multipara & 30 & 75 & 19 & 47.5 & \\
Duration of contraceptive use (years) & & & & & \\
$\leq 3$ & 13 & 32.5 & 23 & 57.5 & \\
$>3$ & 27 & 67.5 & 17 & 42.5 & \\
\hline \hline
\end{tabular}

Table 2. HPV 16 and 18 Infections in the Cervix of Study Participants

\begin{tabular}{|c|c|c|c|c|c|c|c|c|c|c|}
\hline \multirow{3}{*}{ Subjects } & \multicolumn{4}{|c|}{ HPV 16} & \multicolumn{6}{|c|}{ HPV 18} \\
\hline & \multicolumn{2}{|c|}{ Positive } & \multicolumn{2}{|c|}{ Negative } & \multirow[t]{2}{*}{$p$} & \multicolumn{2}{|c|}{ Positive } & \multicolumn{2}{|c|}{ Negative } & \multirow[t]{2}{*}{$p$} \\
\hline & $\mathbf{n}$ & $\%$ & $\mathbf{n}$ & $\%$ & & $\mathbf{n}$ & $\%$ & $\mathbf{n}$ & $\%$ & \\
\hline Users $(n=40)$ & 1 & 2.5 & 39 & 97.5 & \multirow{2}{*}{1.000} & 0 & 0 & 40 & 100 & \multirow{2}{*}{1.000} \\
\hline Control $(n=40)$ & 0 & 0 & 40 & 100 & & 1 & 2.5 & 39 & 97.5 & \\
\hline
\end{tabular}

Table 3. Cervical Cytology Results using Liquid-based Cytology (LBC) Method

\begin{tabular}{|c|c|c|c|c|c|}
\hline \multirow{3}{*}{ Subjects } & \multicolumn{5}{|c|}{ Changes in cervical cytology } \\
\hline & \multicolumn{2}{|c|}{ Positive } & \multicolumn{2}{|c|}{ Negative } & \multirow[t]{2}{*}{$p$} \\
\hline & $\mathbf{n}$ & $\%$ & $\mathbf{n}$ & $\%$ & \\
\hline Users $(n=40)$ & 24 & 60 & 16 & 40 & \multirow{2}{*}{0.26} \\
\hline Control $(n=40)$ & 19 & 47.5 & 21 & 52.5 & \\
\hline
\end{tabular}

\section{DISCUSSION}

In the present study, we found that there was no significant difference of HPV types 16 and 18 infections between combined hormonal contraceptive users and control. This result similar to the study by Morgan et al. that follow up 1135 women (consists of 376 combined oral contraceptives users, 331 DMPA users and 428 non-contraceptive users) for 18 months. They found new HPV infection in 269 women and high-risk HPV infection in 157 women. $^{8}$ However, HPV infection and COCs was not statistically significant after adjusting for age, a number of sexual partners, bacterial 
vaginosis and duration of the COCs and DMPA use. Study also that COCs was not associated with the risk of cervical infection whereas DMPA use significantly associated with the risk of cervical infection primarily by chlamydial and gonococcal infections ${ }^{5}$ but in another study show that cervical carcinoma risk increases by up to four-fold in women positive for cervical HPV DNA after long-term use of oral contraceptives. ${ }^{9}$ Study by Urban show that use of oral and of injectable hormonal contraceptives was associated with a transiently increased risk of breast and cervical cancer after using the contraceptives for 5 years but not differ significant. ${ }^{10}$

Although women are infected with HPV cervical, most do not develop into cervical cancer. Several factors are also involved in the development of cervical cancer. Exogenous or environmental factors such as the use of hormonal contraceptives, smoking, parity and infections along with sexually transmitted diseases; viral factors such as the specific type of infection, co-infection with other HPV types, variants of HPV, viral load and viral integration; and host factors include endogenous hormones, genetic factors and other factors related to the immune response. ${ }^{11}$ The number of full-term pregnancies is associated with an increased risk of invasive cervical carcinoma after adjustment for the number of sexual partners and age at first intercourse. ${ }^{12}$ The mechanisms which high parity increases the risk of cervical carcinoma is through the maintenance of the transformation zone on the ectocervix for many years in which may facilitate exposure to HPV. A previous study found that high parity increases the risk of squamous-cell carcinoma of the cervix among HPV-positive women. ${ }^{13}$ This study finding multiparity significantly found difference between users and control.

HPV infects immature basal cells of the squamous epithelium in areas of the immature metaplastic squamous present at the squamo columnar junction. Cervix is a wide area with immature metaplastic squamous epithelium that is highly susceptible to HPV infection. HPV replication took place immature squamous cells results in koilocytotic atypiaconsists of atypic core and halo perinuclear cytoplasmic. Perinuclear halo show typical expression of active phase HPV infection in cervical cytology. ${ }^{14}$ Therefore, other types of HPV infection may be present in the women cervix of the present study both combined hormonal contraceptive users and control.
Cervical cytology results show cervical changes both in users and control but the difference not statistically significant. This results similar to previous studies that found cervical histologically change due to combined hormonal contraceptives use. Effects of $17 \beta$-estradiol from COCs causes progressive metaplasia in the transformation zone that leads to dysplasia in squamous epithelium. ${ }^{15}$ These findings are in disagreement with results from the study by Syrjanen et al., found that COCs was not a significant predictor in women with cervical intraepithelial neoplasia (CIN) $2 / 3$ or highgrade squamous intraepithelial lesion (HSIL) in women with positive and negative HPV infection. They also found that the disease with highoncogenic risk HPV types infection is not correlated to contraception. ${ }^{16}$ Most HPV infection is asymptomatic and does not change the cervical tissue; therefore, cervical changes could not be detected on Pap smear. Some studies found the majority of HPV infections will regress spontaneously within five years, but only a few women with high-risk HPV infection will develop into CIN $2 / 3$ and will eventually cervical cancer. ${ }^{17,18}$

Estrogen increases expression of oncogenic proteins E6 and E7 in HPV as a major stimulant of cervical cancer. ${ }^{19}$ Steroid hormones (estrogen and progesterone) play a role in the initiation and progression of cervical cancer through carcinogenesis. Lesions from HSIL develop into cervical carcinoma reported from women using estra$\operatorname{diol}^{15,20}$

\section{CONCLUSION}

In conclusion, our study show there is no relationship between HPV 16/18 infection and cervical cytology changes among combined hormonal contraceptives users.

\section{REFERENCES}

1. Faridi R, Zahra A, Khalida Khan K, Idrees M. Oncogenic potential of Human Papillomavirus (HPV) and its relation with cervical cancer. J Virol 2011; 8: 269.

2. Bruni L, Diaz M, Castellsague X, et al. Cervical human papilloma virus prevalence in 5 continents: meta-analysis of 1 million women with normal cytological findings. J Infect Dis 2010; 202: 1789-99.

3. Marks MA, Klein SL, Gravitt PE. Hormonal contraception and HPV: A tale of differing and overlapping mechanism. Open Access J Contracep 2011; 2: 161-74. 
4. Porras C, Bennett C, Safaeian M, et al. Determinants of seropositivity among HPV-16/18 DNA Positive Young Women. BMC Infect Dis. 2010; 10: 238.

5. Morrison CS, Bright P, Wong EL, et al. Hormonal contraceptive use, cervical ectopy, and the acquisition of cervical infections. Sex Transm Dis. 2004; 31(9): 561-7.

6. Baziad A. Kontrasepsi hormonal. Jakarta: Bina Pustaka Sarwono Prawirohardjo. 2008: 18-93.

7. Smith JS, Green J, Berrington de Gonzalez A, et al. Cervical cancer and use of hormonal contraceptive : a systematic review. Lancet. 2003; 361(9364): 1159-67.

8. Marks M, Gravitt PE, Gupta SB, et al. Combined oral contraceptive use increases HPV persistence but not new HPV detection in a cohort of women from Thailand. J Infect Dis. 2011; 204(10): 1505-13.

9. Moreno V, Bosch FX, Muñoz N, et al. Effect of oral contraceptives on risk of cervical cancer in women with human papilloma virus infection: the IARC multicentric case-control study. Lancet. 2002; 359(9312): 1085-92.

10. Urban M, Banks E, Egger $S$, et al. Injectable and oral contraceptive use and cancers of the breast, cervix, ovary, and endometrium in Black South African Women: case-control study. PLoS Med 2012; 9(3): e1001182.

11. Muñoz N, Castellsagué X, de González AB, Gissman L. Chapter 1: HPV in etiology of human cancer. Vaccine 2006; 24: S3/1-10.

12. International Collaboration of Epidemiological Studies of Cervical Cancer. Cervical carcinoma and reproductive factors: collaborative reanalysis of individual data on 16,563 women with cervical cancer and 33,542 women without cervical cancer from 25 epidemiological studies. Int J Cancer 2006; 119: 1108-24.
13. Muñoz N, Franceschi S, Bosetti C, et al. Role of parity and human papilloma virus in cervical cancer: the IARC multi centric case-control study. Lancet. 2002; 359(9312): 1093101.

14. Ellenson LH, Pirog EC. The female genital tract. In: Kumar V, Abbas AK, Aster JC. Robbins and Cotran : Pathologic basis of diseases. $9^{\text {th }}$ ed. Canada. Elsevier-Saunders. 2005: 1002-4.

15. Elson DA, Riley RR, Lacey A, et al. Sensitivity of the cervical transformation zone to estrogen-induced squamous carcinogenesis. Cancer Res. 2000; 60(5): 1267-75.

16. Syrjanen S. Human papillomavirus infections and oral tumors. Med Microbiol Immunol 2003; 192: 123-8.

17. Frazer I. Correlating immunity with protection for HPV infection. Int J Infect Dis. 2007; 11(2): S10-6.

18. Muñoz N, Hernandez-Suarez G, Méndez F, et al. Persistence of HPV infection and risk of high grade cervical intraepithelial neoplasia in a cohort of Colombian Women. Br J Cancer. 2009; 100(7): 1184-90.

19. Chung SH, Franceschi S, Lambert PF. Estrogen and ERalpha: culprits in cervical cancer? Trends Endocrinol Metabol. 2010; 21(8): 504-11.

20. de Villiers EM. Relationship between steroid hormone contraceptives and HPV, cervical intraepithelial neoplasia and cervical carcinoma. Int J Cancer 2003; 103: 705-8. 